\title{
Improving Religiosity Among Religious Communities Through Church Service
}

\author{
Johari Manik \\ IAKN Tarutung \\ manik.johari@iakntarutung.ac.id
}

\begin{abstract}
This study belongs to descriptive quantitative research using questionnaire as the instrument to gather the data. The population of the study was all the HKBP church in Siraja Hutagalung that was then taken the sample by using random sampling technique. Before using the questionnaire to gather the data, validity and reliability were measured first and it lasting with valid and reliable. Harmony among religions needs to be a concern of the church as a Christian denomination tasks to do. In data analysis there was a data reduction since the raw data were various from the informant. This research aims to find out how the role of the church is, in realizing and increasing harmony between/among religions. The result of the study revealed an increase in harmony among religious communities through church services in Siraja Hutagalung Village, Siatas Barita Tarutung District in 2018, within 2.94 increase, which means that the church plays a good role in increasing religious harmony.
\end{abstract}

Keywords: Improving religiosity, church services, harmony, among religious communities

\section{Introduction}

Indonesian nation has pluralistic society, and it can be a potential disintegrative if it is not handled wisely. From the religion side, pluralism will be very potential to cause disunity if each religion accentuates the truth of their respective religion beyond a reasonable proposition, see (A.A. Yewangoe, 2009: 26). The prolonged crisis that made Indonesian people lately has added to the extent of poverty and in turn has also resulted in the depletion of a sense of community tolerance, so easily causing conflicts between or among religions. This can be seen with the closure and forcible destruction of several houses of worship (churches) in Indonesia by irresponsible people, for reasons that are also unclear, such as: Situbondo tragedy which resulted in the burning of several church buildings. Banjarmasin riots which resulted in the destruction and burning of church buildings. Destruction of nine churches in Surabaya without apparent reasons. And in 2018 there was the destruction of three churches due to bombing by terrorists. Mass action in Kupang that burns Mosques and stalls belonging to Bugis and Makassar people who are Muslim. The case of the Ahmadiyah congregation, Bogor, West Java, in early July 2005 was intimidated accompanied by acts of violence by the masses labeled Islam. And, the Ahok case which is considered to be a religious division sacred verse that was considered to be dabbled, also the case of Ibrahim which is seen as effort of Christianize.

Harmony among religions has been carried out in Indonesia, with dialogue being held at both the central and provincial levels, interfaith activities, etc. The role and The prolonged crisis that 
befell the Indonesian people lately has added to the extent of poverty and in turn has also resulted in the depletion of a sense of community tolerance, so easily the cause of conflicts that reek of religion. A.P. Budiyono HD (1995: 37) cites the opinion of Piet Maku Waso who wrote that: "Harmony in the sense of" harmony "can also cause someone to say that they have shown harmony, instead tolerate it until they themselves become victims, which is actually not the case, or say that other people / parties get along well with him even though he looks with dark glasses all suspiciously ... if it says "the Ali lives in harmony according to his religion", it means that Ali lives while living Islamic laws. And if people say "Ali lives in harmony with his wife", it means that Ali lives while carrying out Islamic religious laws that regulate a reasonable and good relationship between him and his wife ..."

From the description above, that the word "rukun" means to be carried out in accordance with each law. So the writer can conclude that the notion of harmony can not be separated from the role of "law". Laws are regulations, laws governing the association of community life in accordance with the points of Pancasila; God Almighty, Just and Civilized Humanity, Indonesian Unity, Society led by Wisdom Wisdom in Consultation and Representation, and Social Justice for all Indonesian people. According to Pattiasina J.M. (1997: 218) there are seven elements that are included in the understanding of harmonious life:

a) The word harmonious refers to subjects who have conscious personalities.

b) Living in harmony is in togetherness, in the unity of space, place and time.

c) Living in harmony can be said if there is a harmonious and compact relationship.

d) Harmony is desired consciously and freely without coercion.

e) The elements that can unite are togetherness.

f) To foster harmony there needs to be a bond, the same foundation that applies to all parties and is adhered to by all parties. Of course learning for this can be through lectures and lectures.

g) Harmony is also not detrimental to each other but it appears in a compact cooperation that is in dealing with joint problems.

Weinata Sairin (2002: 83) cites the opinion of Okta Diputera who said "religious harmony is the creation of a harmonious and dynamic relationship, harmony and peace among fellow religious communities in Indonesia, namely a harmonious relationship between fellow believers in one religion, between religious communities. with the government ". Furthermore, Einar Sitompul (2004: 17) states, "The church does not have to change with the times, but the church must be able to change the conditions of the times for the better. Therefore it is necessary to take a cultural approach ". Whereas, according to A.P.Budiyono H.D. (1995: 219-220) that in realizing and increasing harmony among religious communities can be done in the form of: 1) Dialogue between religions, 2) Togetherness, 3) Social community cooperation, 4) Tolerance, 5) Awareness, 6) Unity and integrity, 7) Respectful Respect, 8) Deliberation. The best solution to resolve an event or conflict requires the role of deliberation. Seeing the increasing tension, it is necessary to hold a deliberation, through the Interfaith Cooperation Agency (BKAA) or if at the center of the Interfaith Conference (WMAA). 


\section{Method}

\section{a) Population and Sample}

Arikunto (2010: 173) said "The population is the whole subject under study that can be used as a source of data for a researcher". From this opinion contained an understanding that the population is the whole subject to be studied. From the results of the data collection, data were obtained that the population of the village of Hutagalung Harean was 300 families and 550 people. Source: Siraja Hutagalung Village Office, Kec. Siatas Barita, Tarutung

The sample is part or representative of the population studied. According to Arikunto (2010: 174) said that "The sample is part or represents of population. If the subject is less than 100 people, it is better to take all of it so that the research is a population study. Furthermore, if the number of subjects is more than 100 people, then the sample is taken at $10-15 \%$ or more depending on the ability of researchers.

From the opinion above, the authors take a sample of $15 \%$ of the total population of $550 \mathrm{x}$ $10 \%=55$. The research hypothesis is tested with the provisions that if the average range of $2.50-$ 4.00 then the hypothesis is accepted, and if the average value is within the range of $1.00-2.49$ the hypothesis is rejected. Based on the results of the study above shows that the average value of the aspects studied are:

$$
\begin{aligned}
& X=\frac{\text { Jumlahrata }- \text { rata }}{n}= \\
& X=\frac{88.13}{55}=2.94
\end{aligned}
$$

So it can be concluded that the increase in harmony among religious communities through church services is expressed as good with a value of 2.94 on a scale of $2.60-3.59$. Based on these results, the hypothesis is accepted by "An increase in harmony among religious communities through church services in Siraja Hutagalung Village, Siatas Barita Tarutung District in 2018".

\section{b) Data Collection Instruments}

To collect data in this study the author used a random technique. Data collection through a questionnaire is carried out with the following steps:

1) Gather respondents.

2) Give direction so that they are honest in answering the questions.

3) Guide the respondent to answer the question clearly and direct the questions that do not understand.

4) Collecting the questionnaire at that time also records all the results of filling out the questionnaire into a table. 


\section{Results and Discussion}

Based on the results of data collection from the results of respondents' answers, it is known that the item that has the highest weighting value of the 30 items about the Role of the Church in Increasing Interfaith Harmony is number 19 with a score of 191 and an average value of 3.47 ie the community views religious adherents others as fellow creatures created by God. While the lowest weight value of the other items is number 5 with a score of 106 and an average value of 1.93, which is the recent event in various regions, namely the bombing and destruction of houses of worship that has strung the strings of brotherhood between religious communities. And this has never happened in this environment.

Calculation of the average value for item number 1, it is known that the average value is 2.87 including the good category. This means that communication between communities is well established. Calculation of the average value for item number 2, it is known that the average value is 2.55, including the less good category. This means that cooperation in humanity for the progress of the nation is still not good enough. Calculation of the average value for item number 3 , note that the average value is 2.58 , including the category of not good. This means that communication in society with a variety of religions has not gone well. Calculation of the average value for item number 4 , note that the average value is 3.04, including good category. This means that brotherhood between religious communities runs well. Calculation of the average value for item number 5 , note that the average value is 1.93 , including the category is not good. It means seeing your fellow believers insulting or defaming another religion. Calculation of the average value for item number 6 , note that the average value is 2.71 including the good category. It means that there is a harmonious life togetherness between brotherhoods of religious communities.

Calculation of the average value for item number 7, note that the average value is 2.96 including the good category. This means that programs such as joint charity work and coaching between religious communities in your community are good. Calculation of the average value for item number 8 , note that the average value is 2.51 , including the good category. It means togetherness to help each other help in religious life well. Calculation of the average value for item number 9 , note that the average value is 2.78 , including the good category. This means that social cooperation in the environment well. Calculation of the average value for item number 10 , note that the average value is 3.04, including good category. This means that cooperation between religious communities in tightening the ties of brotherhood among religious people such as cooperation in the fields of material, energy, and mind with the aim of helping to build a house of worship well. Calculation of the average value for item number 11, note that the average value is 2.56 , including the good category. This means that the feeling of the same fate must be instilled with the younger generation well. Calculation of the average value for item number 12, note that the average value is 3.14 including the good category. This means that the attitude of mutual assistance / support in celebrating religious holidays in the community properly. Calculation of the average value for item number 13, note that the average value is 2.84 including the good category. This means that all citizens behave naturally in diverse religious communities well.

Calculation of the average value for item number 14 , note that the average value is 3.04 , including good category. It means seeing other people's religion from their own perspective and not interfering with the internal affairs of other religions properly. 
Calculation of the average value for item number 15 , note that the average value is 2.76 , including the good category. Meaning In fostering faith, it is also done by "holding religious seminars" well. Calculation of the average value for item number 16, note that the average value is 2.75 including the good category. It means that associating should not distinguish between religions so that the relationship is more harmonious between citizens.

Calculation of the average value for item number 17, note that the average value is 3.20 including the good category. This means that religious awareness in its growth begins with a sense of tolerance in the realization of unity and unity well. Calculation of the average value for item number 18 , note that the average value is 3.09 , including good category. It means seeing the followers of other religions as fellow creatures created by God and fellow countrymen. Calculation of the average value for item number 19, it is known that the average value is 3.47 including the good category. It means as a believer. Do you understand the importance of harmony well. Calculation of the average value for item number 20 , note that the average value is 3.33 , including the good category. This means that faith is seen from actions and actions well. Calculation of the average value for item number 21, note that the average value is 3.27 including the good category. It means to maintain unity and integrity by always trying to relate and work together to maintain harmony in your environment well. Calculation of the average value for item number 22, it is known that the average value is 3.16 including the good category. It means that they feel burdened if an area is affected by disasters, even though they have different religions. Calculation of the average value for item number 23, note that the average value is 3.02 , including the good category. This means that adherents of religion accept and respect the similarities and differences of each religion and do not interfere in the areas of doctrine / creeds / beliefs and practices of worshiping other religions properly.

Calculation of the average value for item number 24 , note that the average value is 3.05 , including the good category. It means to love the followers of other religions well. Calculation of the average value for item number 25 , note that the average value is 3.09 , including the good category. It means treating people of other faiths with good intentions and attitudes, empathy, compassion, and mutual respect. Calculation of the average value for item number 26 , note that the average value is 3.09 , including good category. This means maintaining good mutual respect and respect for other religious communities. Calculation of the average value for item number 27, it is known that the average value is 3.24 including the good category. This means that citizens should further enhance mutual respect and respect between adherents of other religions. Calculation of the average value for item number 28, note that the average value is 3.07 , including the good category. This means that citizens should further enhance mutual respect and respect between adherents of other religions. Calculation of the average value for item number 29, note that the average value is 2.82 , including the good category. It means that solving the problem must be done with deliberation. Calculation of the average value for item number 30 , note that the average value is 2.82 , including the good category.

\section{References}


[2] Alkitab.Lembaga Alkitab Indonesia. Jakarta. (2017

[3] Bronwnlee, Malcolm. Pengambilan Keputusan Etis, Jakarta: BPK Gunung Mulia. (2000)

[4] Budiyono, HD. AP. Membina Kerunanan Hidup Antar Umat Beriman. Jilid. II. pp.37 Yogyakarta: Kanisius. (1995)

[5] Dahlenurg, G. D. Konfesi-Konfesi Gereja Lutheran: Pengantar dan Cuplikan penting KonfesiKonfesi Gereja Lutheran. Jakarta: BPK. Gunung Mulia. (2000)

[6] Hadiwijono, Harun. Iman Kristen, Jakarta: BPK Gunung Mulia. (2001)

[7] Homrighousen, E. G. dan I. H. Enklaar. Pendidikan Agama Kristen. Jakarta: BPK Gunung Mulia. (2000)

[8] Husaini, Adian. Kerukunan Beragama Dan Kontroversi Penggunaan Kata Allah, Gema Insani. Jakarta (2015)

[9] Pattiasina, J. M., dkk. Gerakan Ouikumene Tegar Mekar di Bumi Pancasila. pp.218. Jakarta: BPK Gunung Mulia (1997)

[10] Sairin, Weinata, Gereja Agama-agama dan Pembangunan Nasional. pp.83, Jakarta: BPK Gunung Mulia (2006)

. (2010) Kita Harap Tuhan Yang Terbaik bagi Gereja dan Bangsa.. Majalah Narwastu (2010)

[12] Sitompul, Einar. Gereja Menyikapi Perubahan. Jakarta. BPK Gunung Mulia (2004)

[13] Yewangoe. A. A. Agama dan Kerukunan. pp.26. Jakarta: BPK Gunung Mulia (2002) 